\title{
Traction performance simulation for mechanical front wheel drive tractors: towards a practical computer tool
}

\author{
A. Battiato, ${ }^{1,2}$ E. Diserens, ${ }^{1}$ L. Sartori ${ }^{2}$ \\ ${ }^{1}$ Agroscope Reckenholz-Tänikon Research Station ART, Ettenhausen, Switzerland; \\ ${ }^{2}$ Land, Environment, Agriculture and Forestry Department, University of Padua, Italy
}

\begin{abstract}
An analytical model to simulate the traction performance of mechanical front wheel drive MFWD tractors was developed at the Agroscope Reckenholz-Tänikon ART. The model was validated via several field tests in which the relationship between drawbar pull and slip was measured for four MFWD tractors of power ranging between 40 and $123 \mathrm{~kW}$ on four arable soils of different texture (clay, clay loam, silty loam, and loamy sand). The pulling tests were carried out in steady-state controlling the pulling force along numerous corridors. Different configurations of tractors were considered by changing the wheel load and the tyre pressure. Simulations of traction performance matched experimental results with good agreement (mean error of $8 \%$ with maximum and minimum values of $17 \%$ and $1 \%$ respectively). The model was used as framework for developing a new module for the excel application TASCV3.0.xlsm, a practical computer tool which compares different tractor configurations, soil textures and conditions, in order to determine variants which make for better traction performance, this resulting in saving fuel and time, i.e. reducing the costs of tillage management.
\end{abstract}

\footnotetext{
Correspondence: Andrea Battiato, Agroscope Reckenholz-Tänikon Research Station ART, Tänikon 1, 8356 - Ettenhausen, Switzerland.

Tel. +41.(0)52.368.3332 - Fax: +41.(0)52.365.1190.

E-mail:andrea.battiato@agroscope.admin.ch

andrea.battiato@studenti.unipd.it
}

Key words: Drawbar pull, MFWD tractor, Traction performance, Wheel slip.

Contributions: the authors contributed equally.

Conflict of interests: the authors declare no potential conflict of interests.

Acknowledgements: we wish to acknowledge the Swiss Federal Office for the Environment FOEN and the tyre manufacturer Michelin for providing the financial support for this study.

(C) Copyright A. Battiato et al., 2013

Licensee PAGEPress, Italy

Journal of Agricultural Engineering 2013; XLIV(s2):e67

doi:10.4081/jae.2013.s2.e67

This article is distributed under the terms of the Creative Commons Attribution Noncommercial License (by-nc 3.0) which permits any noncommercial use, distribution, and reproduction in any medium, provided the original author(s) and source are credited.

\section{Introduction}

Since the traction performance of a tractor has a major impact on both fuel consumption and the time required for soil tillage, optimising this performance is clearly of crucial importance in tillage management.

The traction performance of a tractor depends on many factors such as soil mechanical behaviour, wheel load, tyre inflation pressure, wheel dimensions and number, tractor geometry (wheelbase and drawbar height), engine power, and inclination of the pulling force. While most of these factors are more or less constrained, some of them, such as wheel load, tyre pressure, or number of drive wheels, can be easily managed in order to improve the traction performance of the tractor.

Effects of tractor configuration on fuel consumption, specific fuel consumption, and work-rate were reported by Lyne et al. (1984) and Serrano et al. (2009). Jenane et al. (1996) observed that operating at optimum tractive efficiency allows the minimum specific fuel consumption.

This study was aimed to develop a practical computer application for simulating traction performance of MFWD tractors under several configurations and on different soils. This application will be presented as a new module of the software TASC developed at the Agroscope Reckenholz-Tänikon Research Station ART (Diserens et al., 2003).

The application is based on an analysis of the stress-strain interaction at soil-tyre contact surface with the model presented by Shmulevich and Osetinsky (2003) and Osetinsky and Shmulevich (2004). Models of soil-pneumatic wheel interaction based on Bekker's theory (Bekker, 1956) were previously presented by Bekker (1960), Fujimoto (1977) and Schmid (1995). Bekker (1960) assumed the contact surface between soil and tyre to be a combination of a flattened portion and the unloaded contour, Fujimoto (1977) proposed to replace the elastic tyre with a bigger rigid wheel within the area of contact with soil, whilst Schmid (1995) introduced a parabolic configuration of the tyre-soil contact surface with the apex at the front point of contact. The approach of a parabolic shaped contact surface was used later, in a modified form, by Shmulevich and Osetinsky (2003).

\section{Materials and methods}

\section{Soil-tyre interaction modelling for a MFWD tractor}

The main forces acting on the driven pneumatic wheel are shown in Figure 1, with a detail of the elementary forces acting at soil-tyre contact, according to Shmulevich and Osetinsky (2003).

The model assumes the soil to behave as a plastic non-linear medium, the wheel to roll in steady-state motion at a low velocity, and the tyre to deform in linear elasticity. The soil-tyre contact surface in the longitudinal direction has a parabolic form with the apex at the rear 
point of contact $A$ (Figure 1), and the wheel-soil interaction is two dimensional (plane-strain problem). This latter assumption implies that the rut depth is the same across the width, and the width is the same along the contact surface, moreover all values are referred to the unit width of the wheel.

The soil-tyre interaction model was adapted for a MFWD tractor by introducing the load transfer effect and the multipass effect.

The dynamic wheel load due to load transfer effect was considered on the basis of the equilibrium condition of the tractor body (Figure 2), as follows:

$W_{f}=W_{0, f}-\Delta W$

for the front wheel and

$W_{r}=W_{0, r}+\Delta W$

for the rear wheel.

The terms $W_{0, f}$ and $W_{0, r}$ are the stationary wheel loads on the front wheel and rear wheel, respectively, whereas $W_{f}$ and $W_{r}$ are the wheel loads in dynamic conditions on the front wheel and rear wheel, respectively. The term $\mathrm{D} W$ is the load transferred, calculated as:

$\Delta W=\frac{T_{f}+T_{r}+\left(N T_{f}+N T_{r}\right)\left(h-R_{r, r}\right)+N T_{f}\left(R_{r, r}-R_{r, f}\right)}{L}$

in which $T_{f}, N T_{f}, R_{r, f}$ and $T_{r}, N T_{r}, R_{r, r}$ are in order the total driving torque, the net traction and the rolling radius of the front wheel and the rear wheel, respectively, $h$ is the height of the drawbar measured on the field in the operating configuration and $L$ is the wheelbase of the tractor (Figure 2).

Equation 3 is derived assuming the rolling radius to be a good approximation of the height of the wheel hub and to be constant, and the rut depth small enough to be neglected in the calculation. Moreover this equation is valid when the pulling force is applied horizontally, which means that the total tractor weight remains constant and only its distribution between the front and rear axles changes.

The multipass effect accounts for the different mechanical behaviour of soil interacting with the front wheel and the rear wheel, this was considered by means of a differentiated soil mechanical characterization with bevameter tests before tractor passage as well as on the rut left from the passage of the front wheel, according to Bekker (1960).

For a tractor with rigid coupling between the front and the rear axles, the ratio of the theoretical speed of the front wheel to that of the rear wheel $K_{s}$ is fixed, and therefore there is a precise relationship between the slip of the front wheel $i_{\text {front }}$ and that of the rear wheel $i_{\text {rear }}$ in straight line motion:

$i_{\text {front }}=1-\frac{\left(1-i_{\text {rear }}\right)}{K_{s}}$

Preliminary tests with the four MFWD tractors, in all configurations considered, have indicated values of $K_{s}$ very close to 1 (between 0.993 and 1.016), this allowed a simplified analysis in which the slip of the front wheel and that of the rear wheel were assumed to be the same.

\section{Design of field tests}

Several traction tests were carried out with a Hürlimann H488 DT $(65 \mathrm{~kW}, 40.8 \mathrm{kN})$ chosen as reference tractor for this study. Additional traction tests were carried out with a FIAT 50-66 DTS $(40.4 \mathrm{~kW}, 25.3$ $\mathrm{kN}$ ), a John Deere 6920 (110 kW, $66.7 \mathrm{kN})$, and a John Deere 6930 (123 $\mathrm{kW}, 68 \mathrm{kN})$.

The pulling force was obtained by means of a second tractor used as braking machine. In this case were used different tractors having weight always higher than the pulling tractor.
The pulling and the braking tractors were connected by a steel cable and moved aligned as sketched in Figure 3. The traction force was measured by a load cell in section with the steel cable. The actual forward velocity was measured by a radar velocity sensor, whilst the wheel rolling velocity was registered by means of a wireless wheel speed sensor of two pulses per wheel revolution set on a rear wheel of the pulling tractor. All these parameters were recorded and displayed by an auto-
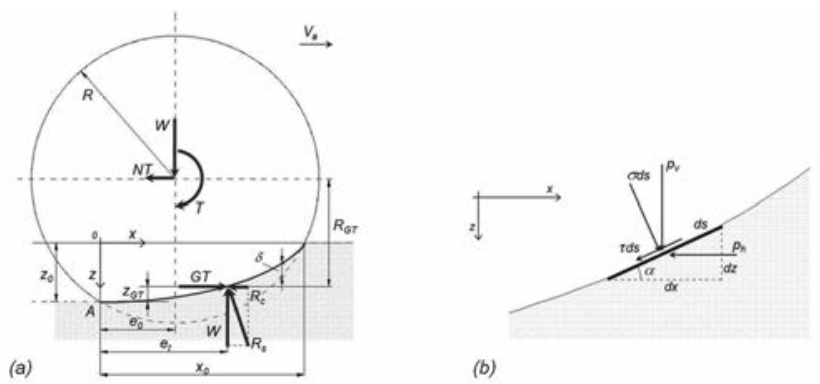

Figure 1. Interaction between soil and a driven pneumatic wheel (a) with the detail of the elementary forces at soil-tyre contact (b) according to Shmulevich and Osetinsky (2003).

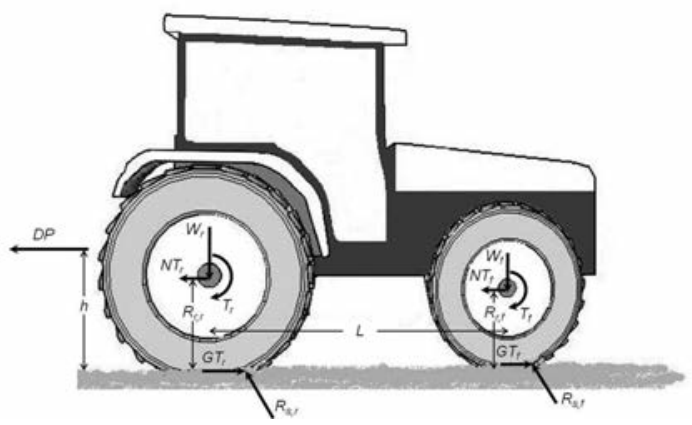

Figure 2. Forces on a MFWD tractor.

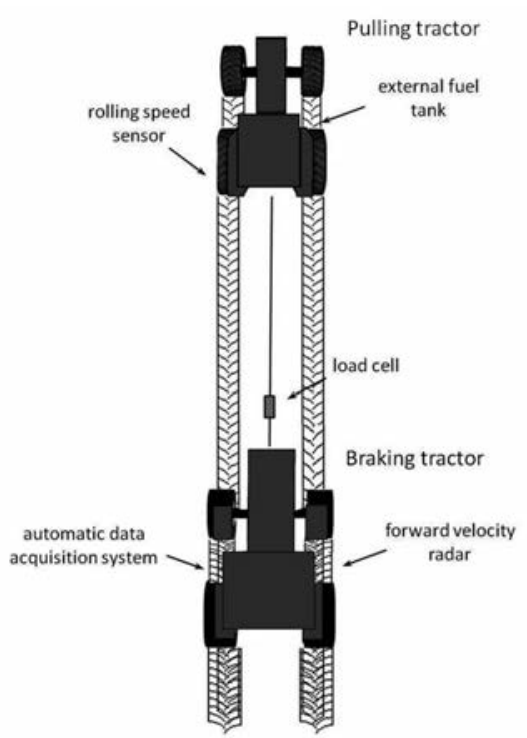

Figure 3. Layout of the tractor pulling test. 
matic acquisition system in the braking tractor. The stationary wheel load was measured with flat bed scales.

Different tractor configurations were considered by changing tyre inflation pressure and wheel load (Table 1).

The traction tests were carried out on four sites having different soil textures. Physical and mechanical parameters of topsoil ( $0-10 \mathrm{~cm}$ depth) of the four sites are reported in Table 2 . The volumetric water content was measured by means of a time domain reflectometry (TDR) device with two-rod single diode probes at a depth of $10 \mathrm{~cm}$. The water potential at $10 \mathrm{~cm}$ of depth was measured with field tensiometers.

The mechanical parameters of soil required for the simulation were obtained on the basis of vertical plate penetration tests and horizontal plate shear deformation tests (Bekker, 1960) with a tractor-mounted bevameter (Figure 4) (Diserens and Steinmann, 2003). The bevameter has a massive frame with a central jack powered by the hydraulic system of the tractor. A laptop is used as datalogger. The vertical force and the axle torque are measured by a load cell and a torque cell, respectively. The soil sinkage is measured by means of an ultrasound sensor which stands on a tripod frame and reflects the signal on a specific surface on top of the compression plate (Figure 4B). The rotation of the lugged plate (Figure $4 \mathrm{C}$ ) is measured by a tachometer.

The penetration tests were repeated with two circular plates of 20 and $30 \mathrm{~cm}$ in diameter in order to account for the influence of the tyre width on the pressure-sinkage relationship of soil (Bekker, 1960). Both the penetration tests and the shear deformation tests were executed according to indications reported by Bekker (1956) and Bekker (1960), and parameters $K_{c}, K, n, c$, and $k$ (Table 2) were determined according to the procedure described by Wong (1980).
In order to consider the multipass effect, the mechanical tests were executed before tractor passage as well as on the rut left from the passage of the front wheel. Parameters $K_{c}, K$ and $n$ calculated before and after the passage of the front wheel changed significantly in the clay soil but not in the other locations which were widely trafficked, conse-

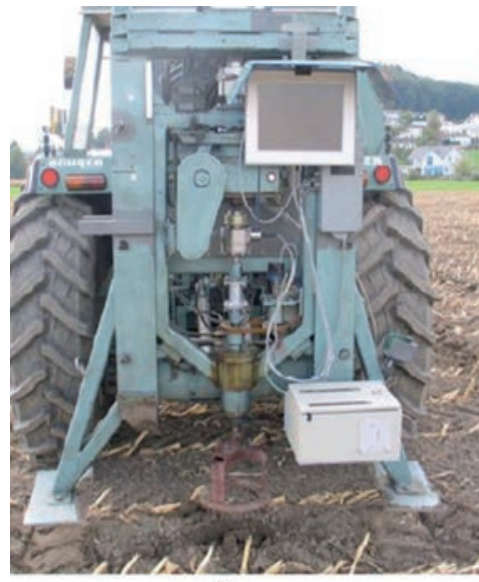

(A)

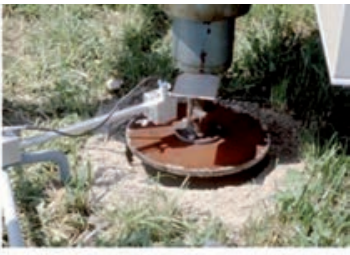

(B)

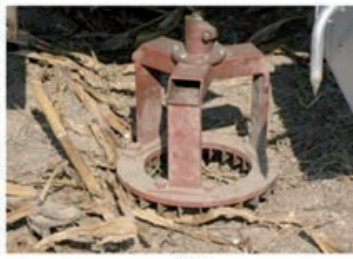

(C)
Figure 4. The tractor-mounted bevameter $(A)$, the circular plate $(30 \mathrm{~cm}$ wide) for compression tests $(B)$, and the lugged plate for shear tests (C).

Table 1. Configurations of tractors.

\begin{tabular}{|c|c|c|c|c|}
\hline Tractor & Configuration & $\begin{array}{l}\text { Tyre } \\
F / R^{*}\end{array}$ & $\begin{array}{l}\text { Wheel load [kN] } \\
\text { C/ CL/ SL / LS** }\end{array}$ & $\begin{array}{c}\text { Tyre Pressure [kPa] } \\
\text { C / CL / SL/ LS }\end{array}$ \\
\hline $\begin{array}{l}\text { Hürlimann H488 DT } \\
65 \mathrm{~kW} \\
\mathrm{~F}=(380 / 85 \mathrm{R} 24) \\
\mathrm{R}=(420 / 85 \mathrm{R} 34)\end{array}$ & $\begin{array}{l}2 \\
3 \\
4\end{array}$ & $\begin{array}{l}\mathrm{F} \\
\mathrm{R} \\
\mathrm{F} \\
\mathrm{R} \\
\mathrm{F} \\
\mathrm{R} \\
\mathrm{F} \\
\mathrm{R}\end{array}$ & $\begin{array}{c}9.1 / 9.1 / 9.1 / 9.1 \\
10.9 / 10.9 / 10.9 / 10.9 \\
9.1 / 9.1 / 9.1 / 9.1 \\
10.9 / 10.9 / 10.9 / 10.9 \\
10.3 / 10.3 / 10.3 /- \\
14.3 / 14.3 / 14.3 /- \\
10.3 / 10.3 / 10.3 /- \\
160 / 160 / 160 /-\end{array}$ & $\begin{array}{c}60 / 60 / 60 / 60 \\
60 / 60 / 60 / 60 \\
160 / 160 / 160 / 160 \\
160 / 160 / 160 / 160 \\
60 / 60 / 60 /- \\
60 / 60 / 60 /- \\
14.3 / 14.3 / 14.3 /- \\
160 / 160 / 160 /-\end{array}$ \\
\hline $\begin{array}{l}\text { FIAT 50-66 DTS } \\
40.4 \mathrm{~kW} \\
\mathrm{~F}=(8.3 \mathrm{R} 24) \\
\mathrm{R}=(230 / 95 \mathrm{R} 36)\end{array}$ & $\begin{array}{l}1 \\
2 \\
3 \\
4\end{array}$ & $\begin{array}{l}\mathrm{F} \\
\mathrm{R} \\
\mathrm{F} \\
\mathrm{R} \\
\mathrm{F} \\
\mathrm{R} \\
\mathrm{F} \\
\mathrm{R}\end{array}$ & $\begin{array}{l}-/ 5.8 /-/- \\
-/ 6.3 /-/- \\
-/ 5.8 /-/- \\
-/ 6.3 /-/- \\
-/ 7.0 /-/- \\
-/ 10.7 /-/- \\
-/ 7.0 /-/- \\
-/ 10.7 /-/-\end{array}$ & $\begin{array}{l}-/ 60 /-/- \\
-/ 90 /-/- \\
-/ 160 /-/- \\
-/ 180 /-/- \\
-/ 60 /-/- \\
-/ 90 /-/- \\
-/ 160 /-/- \\
-/ 180 /-/-\end{array}$ \\
\hline $\begin{array}{l}\text { John Deere } 6920 \\
110 \mathrm{~kW} \\
\mathrm{~F}=(540 / 65 \mathrm{R} 28) \\
\mathrm{R}=(650 / 65 \mathrm{R} 38) \\
\text { John Deere } 6930 \\
123 \mathrm{~kW} \\
\mathrm{~F}=(540 / 65 \mathrm{R} 28) \\
\mathrm{R}=(650 / 65 \mathrm{R} 38)\end{array}$ & $\begin{array}{l}1 \\
2 \\
1 \\
2 \\
3 \\
4\end{array}$ & $\begin{array}{l}F \\
R \\
F \\
R \\
F \\
R \\
F \\
R \\
F \\
R \\
F \\
R\end{array}$ & $\begin{array}{l}-/ 14.1 /-/- \\
-/ 19.1 /-/- \\
-/ 14.1 /-/- \\
-/ 19.1 /-/- \\
-/-/-/ 14.7 \\
-/ / /-/ 19.3 \\
-/-/-/ 14.7 \\
-/-/-/ 19.3 \\
-/ / /-/ 14.3 \\
-/-/-/ 31.0 \\
-/-/-/ 14.3 \\
-/-/-/ 31.0\end{array}$ & $\begin{array}{l}-/ 50 /-/- \\
-/ 50 /-/- \\
-/ 140 /-/- \\
-/ 140 /-/- \\
-/-/-/ 60 \\
-/-/-/ 60 \\
-/-/-/ 140 \\
-/-/-/ 180 \\
-/-/-/ 60 \\
-/-/-/ 60 \\
-/-/-/ 140 \\
-/-/-/ 180\end{array}$ \\
\hline
\end{tabular}

${ }^{*}$ F, Front tyre; R, Rear tyre. ${ }^{* *}$ C, clay; CL, clay loam; SL, silty loam; LS, loamy sand. 
quently they were differentiated for soil interacting with the front wheel $\left(K_{c, f}, K_{, f}, n_{f}\right)$ and soil interacting with the rear wheel $\left(K_{c, r}, K_{r, r}, n_{r}\right)$, as reported in Table 2 . The shear parameters $c$, and $k$ did not change significantly before and after the passage of the front wheel in all locations and for these a unique characterization was adopted.

The tyre rolling radius $R_{r}$ was determined according to the ASAE Standard S296.2 as the distance travelled per revolution of the wheel divided by $2 \pi$ when operating at the specified zero condition. This latter was assumed as the vehicle operating in self-propelled condition on a hard surface, such as a smooth road, according to Wismer and Luth (1973).

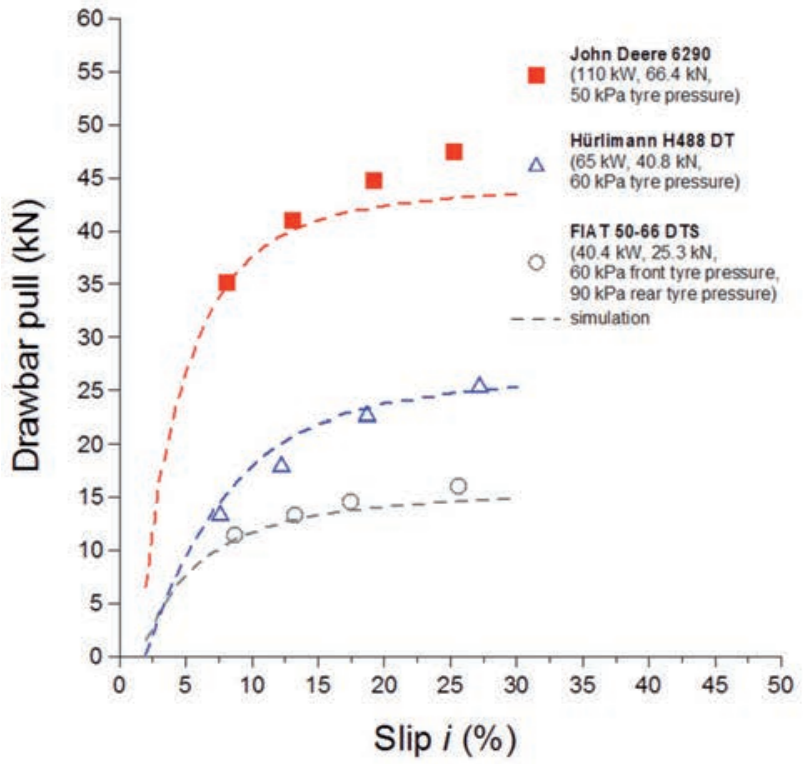

(A)
The stiffness of the tyre was calculated on the basis of tyre dimensions, according to Lines and Murphy (1991).

\section{Results and discussion}

\section{Results of field tests}

Influence of tractor size and power on traction performance is pointed out in Figure 5A, where measured and simulated drawbar pull for

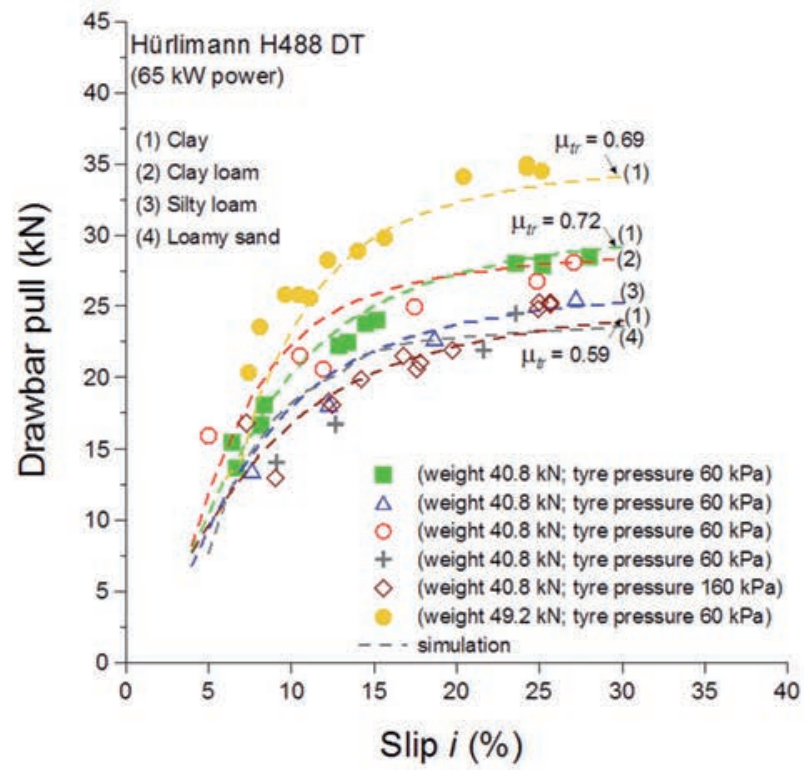

(B)

Figure 5. Measured and simulated traction performance: (A) influence of tractor power on the clay loam; (B) influence of wheel load, tyre pressure, and soil texture.

Table 2. Physical and mechanical parameters of topsoil in the four locations considered.

\begin{tabular}{|c|c|c|c|c|}
\hline Soil property $0-0.10 \mathrm{~m}$ depth & $\mathrm{C}^{*}$ & $\mathrm{CL}^{*}$ & $\mathrm{SL}^{*}$ & LS $^{*}$ \\
\hline Sand [\%] & 20 & 31 & 20 & 84.2 \\
\hline Silt [\%] & 32 & 34 & 53 & 10.1 \\
\hline Clay [\%] & 48 & 35 & 27 & 5.7 \\
\hline Texture (USDA) & clay & clay loam & silty loam & loamy sand \\
\hline Volumetric water content $\theta[\%]$ & 27.0 & 28.4 & 40.2 & 15.2 \\
\hline Water potential $s[\mathrm{kPa}]$ & 6.11 & 9.45 & 1.27 & 57.40 \\
\hline Cohesive modulus of deformation (front) $\mathrm{K}_{c, f}\left[\mathrm{kN} / \mathrm{m}^{(n+1)}\right]$ & 2354.1 & 4554.8 & 298.2 & 1208.2 \\
\hline Frictional modulus of deformation (front) $\mathrm{K}_{\varphi f}\left[\mathrm{kN} / \mathrm{m}^{(n+2)}\right]$ & -4130.0 & -3036.5 & 479.0 & -805.5 \\
\hline Exponent of deformation (front) $\mathrm{n}_{f}$ & 1.01 & 0.90 & 0.77 & 0.81 \\
\hline Cohesive modulus of deformation (rear) $\mathrm{K}_{c, r}\left[\mathrm{kN} / \mathrm{m}\left({ }^{n+1}\right)\right]$ & 2168.9 & 4554.8 & 298.2 & 1208.2 \\
\hline Frictional modulus of deformation (rear) $\mathrm{K}_{\varphi, r}\left[\mathrm{kN} / \mathrm{m}\left({ }^{n+2}\right)\right]$ & -3498.3 & -3036.5 & 479.0 & -805.5 \\
\hline Exponent of deformation (rear) $n_{r}$ & 0.79 & 0.90 & 0.77 & 0.81 \\
\hline Cohesion $c[\mathrm{kPa}]$ & 15.5 & 5.0 & 15.9 & 29.2 \\
\hline Angle of shear resistance $\varphi\left[{ }^{\circ}\right]$ & 26.5 & 30.0 & 25.6 & 6.4 \\
\hline Shear deformation modulus $k[\mathrm{~m}]$ & 0.014 & 0.010 & 0.010 & 0.012 \\
\hline
\end{tabular}

${ }^{*}$ C, clay; CL, clay loam; SL, silty loam; LS, loamy sand 
the FIAT 50-66 DTS, the Hürlimann H488 DT and the John Deere 6920 are compared on the clay loam. As expected, tractors of bigger size and more powerful have higher traction performance.

Influence of variations in wheel load and tyre inflation pressure on traction performance are simulated consistently, as reported in Figure 5B. Here measured and simulated drawbar pull of the Hürlimann H488 DT are compared with and without ballast and at two tyre inflation pressures $(60 \mathrm{kPa}$ and $160 \mathrm{kPa})$ on the clay soil. The effect of variations in wheel load and tyre inflation pressure is also compared in terms of traction coefficient whose value is reported for a slip of $30 \%$, this coefficient is defined as the ratio between the drawbar pull and the tractor load:

$$
\mu_{t r}=\frac{D P}{W_{\text {Tractor }}}
$$

The traction performance depends on the extension of the soil-tyre contact surface as well as on the stress state along this latter. Both the extension and the stress state are controlled by the stiffness of the tyre, the wheel load, and the mechanical behaviour of soil.

According to results reported by Turner (1993) and Zoz and Grisso (2003), an increase in tractor weight (wheel load) makes for higher drawbar pull, however, it doesn't seem to produce a significant variation in terms of traction coefficient.

Increasing wheel load causes, on the one hand, an increase in soil deformation and compaction resistance, on the other hand, the soiltyre contact surface to become more extended. This produced an increase in drawbar pull but did not improve traction performance in terms of the traction coefficient, which decreased slightly (Figure 5B).

With regard to the variation in tyre inflation pressure, many authors have shown the benefits on traction performance of tractors of reduced inflation pressure (Burt and Bailey, 1982; Wood and Mangione, 1992; Upadhyaya and Wulfsohn, 1993; Turner, 1993; Zoz and Grisso, 2003).

A decrease in tyre inflation pressure produces an increase in the traction force as well as in the traction coefficient (Figure 5B), this effect is due to a bigger contact surface between soil and tyre which allows a better use of topsoil strength, especially in cohesive soils which usually present low frictional component of resistance and high cohesive component.

At low tyre inflation pressure the tractor develops, for the same slip, higher drawbar pull than with high tyre inflation pressure or, analogously, it develops the same traction force with less slip. This fact has evident consequences on the energy efficiency of the traction development.

In Figure $5 \mathrm{~B}$ the measured and the simulated drawbar pull of the Hürlimann H488 DT are also compared in the four terrains considered. Physical and mechanical parameters of the topsoil in the four locations were widely different (Table 2), as a consequence, the same tractor configuration produced different traction performance. This confirming that tractor traction performance depends on the tractor-terrain system, being not exclusive peculiarity of tractor configuration.

For a fixed contact surface, the maximum traction is controlled by soil strength, whereas the way the traction is developed with slip is

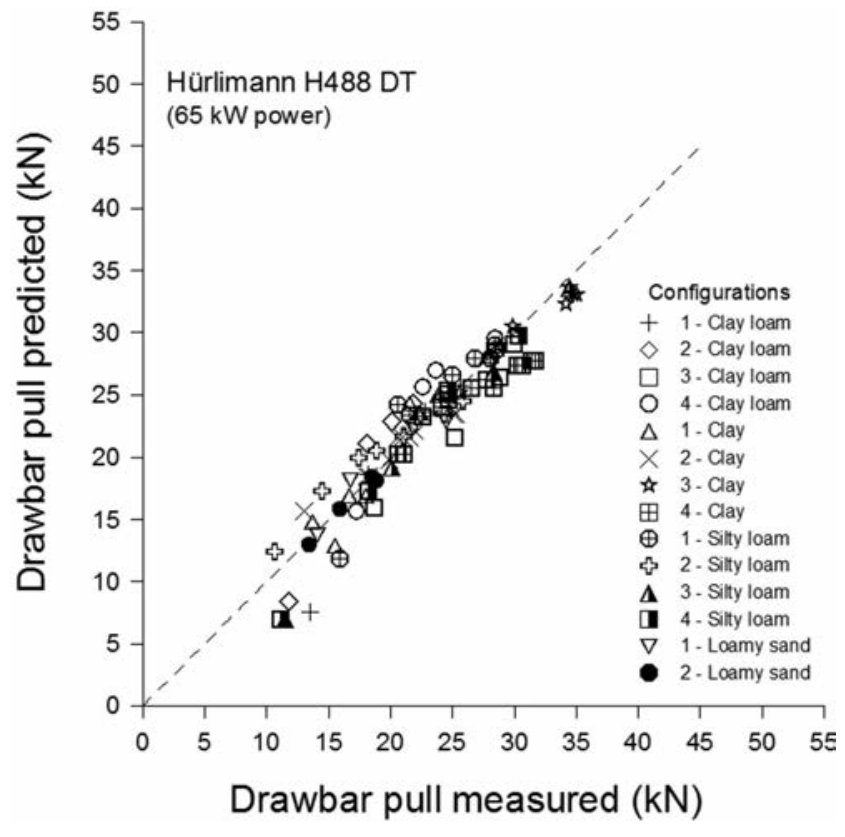

Figure 6. Comparison between measured and simulated drawbar pull of the Hürlimann H488 DT on the four sites for the different configurations considered.

Table 3. Accuracy of traction performance simulations.

\begin{tabular}{|c|c|c|c|}
\hline Tractor & $\begin{array}{l}\text { Configuration } \\
\text { C / CL / SL / LS* }\end{array}$ & $\begin{array}{c}\text { Mean residual [kN] } \\
\text { C / CL / SL / LS* }\end{array}$ & Mean error \\
\hline $\begin{array}{l}\text { Hürlimann H488 DT } \\
65 \mathrm{~kW}\end{array}$ & $\begin{array}{l}1 \\
2 \\
3 \\
4\end{array}$ & $\begin{array}{c}1.00 / 1.86 / 1.61 / 0.98 \\
0.94 / 2.88 / 1.69 / 0.31 \\
1.04 / 2.37 / 1.92 /- \\
1.66 / 2.26 / 1.60 /-\end{array}$ & $\begin{array}{c}0.05 / 0.13 / 0.08 / 0.05 \\
0.05 / 0.17 / 0.10 / 0.02 \\
0.03 / 0.10 / 0.13 /- \\
0.06 / 0.10 / 0.12 /-\end{array}$ \\
\hline $\begin{array}{l}\text { FIAT 50-66 DTS } \\
40.4 \mathrm{~kW}\end{array}$ & $\begin{array}{l}1 \\
2 \\
3 \\
4\end{array}$ & $\begin{array}{l}-/ 0.73 /-/- \\
-/ 0.86 /-/- \\
-/ 0.16 /-/- \\
-/ 0.35 /-/-\end{array}$ & $\begin{array}{l}-/ 0.05 /-/- \\
-/ 0.09 /-/- \\
-/ 0.01 /-/- \\
-/ 0.02 /-/-\end{array}$ \\
\hline $\begin{array}{l}\text { John Deere } 6920 \\
110 \mathrm{~kW}\end{array}$ & $\begin{array}{l}1 \\
2\end{array}$ & $\begin{array}{l}-/ 2.07 /-/- \\
-/ 2.71 /-/-\end{array}$ & $\begin{array}{l}-/ 0.05 /-/- \\
-/ 0.10 /-/-\end{array}$ \\
\hline $\begin{array}{l}\text { John Deere } 6930 \\
123 \mathrm{~kW}\end{array}$ & $\begin{array}{l}1 \\
2 \\
3 \\
4\end{array}$ & $\begin{array}{l}-/-/-/ 4.35 \\
-/-/-/ 1.22 \\
-/-/-/ 1.93 \\
-/-/-/ 2.22\end{array}$ & $\begin{array}{l}-/-/-/ 0.14 \\
-/-/-/ 0.04 \\
-/-/-/ 0.06 \\
-/-/-/ 0.06\end{array}$ \\
\hline
\end{tabular}

${ }^{*} \mathrm{C}$, clay; CL, clay loam; SL, silty loam; LS, loamy sand. 
controlled by the stiffness of soil under shear stress, as measured in the bevameter tests.

From the point of view of the tractor configuration, the drawbar pull rises when the area of interaction between soil and tyre increases. This could be obtained by means of a decrease in tyre inflation pressure, an increase of wheel load or by using dual tyres.

In Figure 6 the measured and predicted drawbar pull of the Hürlimann H488 DT are compared for the different configurations considered (Table 1) in the four sites (Table 2).

In Table 3 the accuracy of the simulation of the drawbar pull is reported in terms of mean residual and mean error for all the configurations considered in our tests.

Model simulations matched experimental measurements with general good agreement within the slip range considered (mean error of $8 \%$ with maximum and minimum values respectively of $17 \%$ and $1 \%$ ).

\section{Development of a new module for TASCV3.0.xlsm}

The validated approach to model tractor traction performance was used as framework for developing a new excel module for the third version of TASC (http://www.agroscope.admin.ch/praxis/00220/06773/ 06777/index.html?lang=en). This module also simulates the topsoil damage from cutting effect due to tyre slip on the basis of an analysis of the stress state at soil-tyre contact surface (Battiato and Diserens, 2011).

For the farmers, three practical tests were set up to allow a fast, simple and reliable mechanical characterization of the topsoil behaviour.

Different tractor configurations, soil textures and conditions can be confronted. TASCV3.0.xlsm offers a valuable support to find out tractor configurations and soil conditions which optimise traction, this resulting in saving fuel and time, i.e. reducing the costs of tillage management.

\section{Conclusions}

This study aimed to develop an analytical model to simulate the traction performance of MFWD tractors on the basis of an analysis of the stress-strain interaction at soil-tyre contact surface.

The model presented matched experimental results with good agreement (mean error of $8 \%$ with maximum and minimum values respectively of $17 \%$ and $1 \%$ ). Moreover, it provided consistent simulations of the effect of variations in tyre pressure and wheel load, and besides, of the influence of soil texture.

A new module for the third version of the excel application TASC is developed on the basis of this model.

This practical computer tool offers a valuable support to find out tractor configurations and soil conditions which optimise traction performance, i.e. which reduce the costs of tillage management.

\section{References}

American Society of Agricultural Engineers 1983. Agricultural engineers yearbook of standards. ASAE Standard S296.2 - Uniform ter- minology for traction of Agricultural Tractors, Self-Propelled Implements, and other Traction and Transport Devices. ASAE, St. Joseph, MI, USA.

Battiato A., Diserens E. 2011. Predicting topsoil damage from slip of tractor tires. Bodenkundliche Gesellschaft der Schweiz. Bulletin 32:21-6.

Bekker M.G. 1956. Theory of Land Locomotion. University of Michigan Press, Ann Arbor, MI, USA.

Bekker M.G. 1960. Off-the-Road Locomotion. University of Michigan Press, Ann Arbor, MI, USA.

Burt E.C., Bailey A.C. 1982. Load and inflation pressure effects on tires. Trans. ASAE. 25:881-4.

Diserens E., Spiess E., Steinmann G. 2003. TASC: a new practical computer tool to prevent soil compaction damage in arable farming. Proc. Int. Conf. Geo-Environmental Engineering, Singapore, pp. 8592.

Diserens E., Steinmann G. 2003. In-situ determination of the fracture point of an agricultural soil using the plate penetration test, comparison with the oedometer method and validation. Proc. Int. Conf. Geo-Environmental Engineering, Singapore, pp. 93-106.

Fujimoto Y. 1977. Performance of elastic wheels on yielding cohesive soils. J. Terramech. 14:191-210.

Jenane C., Bashford L.L., Monroe G. 1996. Reduction of fuel consumption through improved tractive performance. J. Agric. Eng. Res. 64:131-8.

Lines J.A., Murphy K. 1991. The stiffness of agricultural tractor tyres. J. Terramech. 28:49-64.

Lyne P.W.L., Burt E.C., Meiring P. 1984. Effect of tire and engine parameters on efficiency. Trans. ASAE 27:5-7.

Osetinsky A., Shmulevich I. 2004. Traction performance simulation of a pushed/pulled driven wheel. Trans. ASAE 47:981-94.

Schmid I.C. 1995. Interaction of vehicle and terrain results from 10 years research at IKK. J. Terramech. 32:3-26.

Serrano J.M., Peça J.0., Silva J.R., Márquez L. 2009. The effect of liquid ballast and tyre inflation pressure on tractor performance. Biosystems Eng. 102:51-62.

Shmulevich I., Osetinsky A. 2003. Traction performance of a pushed/pulled drive wheel. J. Terramech. 40:35-50.

Turner R.J. 1993. A simple system for determining tractive performance in the field. ASAE/CSAE meeting presentation, ASAE paper No. 931574. ASAE, St. Joseph, MI, USA.

Upadhyaya S.K., Wulfsohn D. 1993. Traction prediction using soil parameters obtained with an instrumented analog device. J. Terramech. 30:85-100.

Wismer R.D., Luth H.J. 1973. Off-road traction prediction for wheeled vehicles. J. Terramech. 10:49-61.

Wong J.Y. 1980. Data processing methodology in the characterization of the mechanical properties of terrain. J. Terramech. 17:13-41.

Wood R.K., Mangione D.A. 1992. Tractive benefits of properly adjusted inflation pressure: Farmer experiences. ASAE paper No. 92-1583. ASAE, St. Joseph, MI, USA.

Zoz F.M., Grisso R.D. 2003. Traction and tractor performance. ASAE distinguished lecture series (Tractor design No. 27), ASAE publication No. 913C0403. ASAE, St. Joseph, MI, USA. 